\title{
Axial variation of basic density of Araucaria angustifolia wood in different diameter classes
}

\author{
Variação axial da massa específica básica da madeira de \\ Araucaria angustifolia em diferentes classes diamétricas
}

\author{
Rômulo Trevisan ${ }^{\mathrm{I}^{*}}$ Alexandre Zanella ${ }^{\mathrm{I}}$ Fernanda Marques da Silva \\ Magda Rosa ${ }^{I}$ Tamires Fioresi ${ }^{I}$ Fabiano de Oliveira Fortes ${ }^{I}$
}

\section{ABSTRACT}

The study of the wood characteristics is of fundamental importance for the correct use of this raw material and, among its properties, the basic density is a major, being reference in the quality of this material. This study aimed to evaluate the axial variation of basic density of the wood of Araucaria angustifolia (Bertoloni) O. Kuntze in different diameter classes. For this, three trees were selected in six diameter classes, called class 1 (20$30 \mathrm{~cm})$, class $2(30.1-40 \mathrm{~cm})$, class $3(40.1-50 \mathrm{~cm})$, class $4(50.1$ $60 \mathrm{~cm})$, class $5(60.1-70 \mathrm{~cm})$ and class $6(70.1-80 \mathrm{~cm})$. From each individual sampled was withdrawn a disc at 0.1m (base), 25, 50, 75 and $100 \%$ of the height of the first live branch and in the diameter at $1.30 \mathrm{~m}$ from the ground $(D B H)$, which were used for determining basic density. The weighted average basic density was equal to $0.422 \mathrm{~g} \mathrm{~cm}^{-3}$ and, regardless of the diameter class analyzed, this property decreased in the axial direction. Diameter induced variation of basic density, but has not been verified a positive or negative systematic tendency in relation to the sampled interval.
\end{abstract}

- NOTE
Key words: Brazilian Pine, wood technological characteristic, wood quality.

\section{RESUMO}

O estudo das características da madeira é de fundamental importância para o correto uso dessa matériaprima e, dentre as suas propriedades, a massa especifica é uma das principais, por ser referência na qualidade desse material. Este estudo teve por objetivo avaliar a variação axial da massa específica básica da madeira de Araucaria angustifolia (Bertoloni) O. Kuntze, em diferentes classes de diâmetros. Para isso, três árvores foram selecionadas em seis classes diamétricas, denominadas de classe 1(20-30cm), classe $2(30,1-40 \mathrm{~cm})$, classe $3(40,1-50 \mathrm{~cm})$, classe $4(50,1-60 \mathrm{~cm})$, classe $5(60,1-70 \mathrm{~cm})$ e classe $6(70,1-80 \mathrm{~cm})$. De cada indivíduo amostrado, foi retirado um disco a 0,1m (base), 25, 50, 75 e $100 \%$ da altura do primeiro galho vivo e no diâmetro a $1,30 \mathrm{~m}$ do solo (DAP), que foram utilizados para a determinação da massa especifica básica. O valor médio ponderado da massa especifica básica foi igual a $0,422 \mathrm{~g} \mathrm{~cm}^{-3}$ e, independentemente da classe diamétrica analisada, essa propriedade decresceu no sentido axial. O diâmetro induziu a variação da massa específica básica, porém não foi verificada uma tendência sistemática positiva ou negativa em relação ao intervalo amostrado.

Palavras-chave: Pinheiro-Brasileiro, característica tecnológica da madeira, qualidade da madeira.

Araucaria angustifolia, for being one of the native species with the highest economic value in southern and southeastern Brazil (HILLIG et al., 2012), due to the historic quality of the wood and its silvicultural characteristics, it has shown great potential for commercial plantations (MATTOS et al., 2006; MATTOS et al., 2011).

However, the proper use of this wood is related to the knowledge of its properties, growing conditions, cutting age of trees, as well as the peculiar variations of the species. The specific mass of the wood, as the result of a complex combination of its internal constituents, is one of the main technological properties used to express quality in various sectors of industrial activity (WASHUSEN et al., 2005; EISFELD et al., 2009; MATTOS et al., 2011). Thus, this study aimed to evaluate the axial variation of basic density

${ }^{\mathrm{I}}$ Departamento de Engenharia Florestal, Universidade Federal de Santa Maria (UFSM), Campus Frederico Westphalen, 98400-000, Frederico Westphalen, RS, Brasil. E-mail: romulo trevisan@ufsm.br. "Corresponding author. 
of the wood of Araucaria angustifolia (Bertoloni) O. Kuntze, as well as the effect of the diameter class in this technological feature in a plantation that is approximately 52 years old.

The material used in this study was collected from a plantation of Araucaria angustifolia, belonging to the National Forest (FLONA) of the city of Passo Fundo, in the state of Rio Grande do Sul. The planting, aged approximately 52 years old, was deployed with an initial spacing of $3.0 \times 2.0 \mathrm{~m}$, and was not subjected to silvicultural treatments.

Selection of the 18 trees analyzed was performed based on the diameter at $1.30 \mathrm{~m}$ from the ground (DAP), where three subjects were sampled in each of the six diameter classes previously defined for inventory and referred to as class $1(20-30 \mathrm{~cm})$, class 2 (30.1-40cm), class $3(40.1-50 \mathrm{~cm})$, class $4(50.1-60 \mathrm{~cm})$, class $5(60.1-70 \mathrm{~cm})$ and class $6(70.1-80 \mathrm{~cm})$. Then, from each selected tree, discs were removed at positions $0.1 \mathrm{~m}$ (base), 25, 50, 75 and 100\% of height of the first live branch and DAP, intended for determination of basic density by relative position and weighted by commercial volume without bark, according to VITAL (1984).

To analyze the effect of the diameter classes in basic density of trees, the data sampled by relative position were submitted to regression analysis using the Statistical Analysis System (SAS, 1993) package, to which the Stepwise regression modelling procedure was first applied. The model was defined by the basic density of the trees $(\rho b)$ in $\mathrm{g} \mathrm{cm}^{-3}$, depending on the relative positions in the base-top direction $(\mathrm{P})$, in $\%$, by using the equation (1): $\rho_{\mathrm{b}}=\mathrm{f}\left(\mathrm{P} ; 1 / \mathrm{P} ; \mathrm{P}^{2} ; 1 / \mathrm{P}^{2} ; \ln \mathrm{P} ; 1 / \ln \mathrm{P}\right)$. (1)

The best model was selected based on the determination coefficient $\left(\mathrm{R}_{\text {aj. }}{ }\right)$, standard error of estimate $\left(\mathrm{S}_{\mathrm{xy}}\right), \mathrm{F}$ value in $5 \%$ level of probability and analysis of the distribution of residuals. After this procedure, Dummy variables were added to the chosen model, which assumed values of 0 and 1, according to the diameter class analyzed, as follows: $\mathrm{Di}=1$, if the tree was present in diametric class $\mathrm{i}$; and $\mathrm{Di}=0$, if the tree was absent in that diametric i class.

With this method, it was possible to express the individual regressions adjusted for the six diameter classes due to a multiple linear regression, represented by the independent variables described in equation (2): $\rho_{\mathrm{b}}=\mathrm{f}\left(\mathrm{X} ; \mathrm{Di}\right.$; Di.X) (2), in which $\rho_{\mathrm{b}}=$ basic density, in $\mathrm{g} \mathrm{cm}^{-3} ; \mathrm{X}=$ relative position (base-top direction) selected by the Stepwise regression procedure, in \%; Di $=$ Dummy (diameter classes, wherein $\mathrm{i}=1 ; \ldots ; 6)$; Di. $X=$ variable interaction Di with $X$ variable.

Average values for the basic density, by position in base-top direction and the weighted basic density due to the commercial volume without bark in each class of diameter, are shown in table 1.

Table 1 - Average basic density per position in the axial direction and weighted basic density based on the commercial volume without bark for all class diameters of Araucaria angustifolia.

\begin{tabular}{|c|c|c|c|c|c|c|c|}
\hline \multirow{2}{*}{ Diametric classes } & \multicolumn{6}{|c|}{-Relative position in the base-top direction---------------------------------- } & \multirow{2}{*}{$\rho_{\text {pond }}(\sigma)$} \\
\hline & $0.1 \mathrm{~m}$ & DAP & $25 \%$ & $50 \%$ & $75 \%$ & $100 \%$ & \\
\hline 1 & 0.499 & 0.453 & 0.428 & 0.429 & 0.370 & 0.343 & $\begin{array}{l}0.420 \\
( \pm 0.058)\end{array}$ \\
\hline 2 & 0.400 & 0.440 & 0.389 & 0.385 & 0.365 & 0.313 & $\begin{array}{l}0.382 \\
( \pm 0.050)\end{array}$ \\
\hline 3 & 0.478 & 0.444 & 0.451 & 0.413 & 0.394 & 0.362 & $\begin{array}{l}0.424 \\
( \pm 0.049)\end{array}$ \\
\hline 4 & 0.472 & 0.468 & 0.407 & 0.411 & 0.347 & 0.378 & $\begin{array}{l}0.418 \\
( \pm 0.055)\end{array}$ \\
\hline 5 & 0.478 & 0.444 & 0.432 & 0.423 & 0.427 & 0.404 & $\begin{array}{l}0.435 \\
( \pm 0.041)\end{array}$ \\
\hline 6 & 0.546 & 0.446 & 0.444 & 0.457 & 0.436 & 0.404 & $\begin{array}{l}0.456 \\
( \pm 0.058)\end{array}$ \\
\hline
\end{tabular}

Wherein: Diametric classes $=1(20-30.1 \mathrm{~cm}), 2(30-40.1 \mathrm{~cm}), 3(40-50.1 \mathrm{~cm}), 4(50-60.1 \mathrm{~cm}), 5(60-70.1 \mathrm{~cm})$ and $6(70-80.1 \mathrm{~cm}) ; \rho_{\text {pond. }}=$ basic density weighted based on the commercial volume without bark, $\mathrm{g} \mathrm{cm}^{-3} ; \sigma=$ standard deviation, $\mathrm{g} \mathrm{cm}^{-3} ; \mathrm{DAP}=$ diameter at $1.30 \mathrm{~m}$ from the ground. 
The results presented, both the arithmetical and weighted average, described for basic density, though still subject to changes by influences of environmental and/or genetic factors at higher ages (WASHUSEN et al., 2005; EISFELD et al., 2009; HILLIG et al., 2012), demonstrated that the timber of Araucaria angustifolia, 52 years old, can be classified as light (MATTOS et al., 2006).

The selected regression equation $\left(\rho_{\mathrm{b}}=0.491-0.012 \sqrt{P}\right)$ to estimate the axial variation of the basic density $\left(\rho_{b}\right)$, in relation to the relative position of the base-top direction $(\mathrm{P})$, presented an adjusted coefficient of determination $\left(\mathrm{R}^{2}{ }_{\text {aj. }}\right)$ of 0.45 , coefficient of variation equal to $9.8 \%$ and a standard error of estimate of $\pm 0,041 \mathrm{~g} \mathrm{~cm}^{-3}$.

Thus, by statistical analysis it was determined that the selected equation cannot be used for all diameters classes (Table 2), because some Dummy's (D2 related to $30-40.1 \mathrm{~cm}$ class and D4 related to $50-60.1 \mathrm{~cm}$ class) employed in the standard model to verify the influence of diameters in the basic density were significant at maximum level of $\alpha=5 \%$ error probability. In table 2, it was also observed that there was no interaction between the classes and the relative position in the base-top direction.

The basic density values for Araucaria angustifolia timber, estimated for six classes of diameter by the equation $\rho_{\mathrm{b}}=0.5003-0.0117 \sqrt{P}-0.0496 \mathrm{D} 2-0.0173 \mathrm{D} 4$ (wherein: $\rho_{\mathrm{b}}=$ specific gravity, $\mathrm{g} \mathrm{cm}^{-3} ; \mathrm{P}=$ relative position in base-top direction, \%; D2 and D4 = Dummy variables matching diameter classes $2(30-40.1 \mathrm{~cm})$ and $4(50-60.1 \mathrm{~cm})$, respectively, can be seen in figure 1 .

The pattern of variation of the basic density for Araucaria angustifolia wood, at 52 years of age, presents a decrease in the axial direction irrespective of the diameter class analyzed; however, it was not possible to set a single equation to estimate the basic density in all classes investigated. The diameter influences the variation of the basic density of the trees, although a systematic increase or decrease with this feature was not verified, it can be concluded that changes in classes did not affect the specific mass uniformly.

Table 2 - Regression analysis of variance with Dummy variable (type SS1) of the basic density of the Araucaria angustifolia wood depending on the diameter class.

\begin{tabular}{|c|c|c|c|c|c|}
\hline $\mathrm{FV}$ & GL & SQ & QM & $\mathrm{F}$ & Prob. $>$ F \\
\hline Modelo & 11 & 0.17668 & 0.01606 & 11.68 & $<.0001^{* *}$ \\
\hline $\mathrm{P} 1$ & 1 & 0.13114 & 0.13114 & 95.40 & $<.0001^{* *}$ \\
\hline D1 & 1 & 0.00011 & 0.00011 & 0.08 & $0.7747^{\mathrm{ns}}$ \\
\hline D2 & 1 & 0.02363 & 0.02363 & 17.19 & $0.0001^{* *}$ \\
\hline D3 & 1 & 0.00179 & 0.00179 & 1.30 & $0.2569^{\mathrm{ns}}$ \\
\hline D4 & 1 & 0.01008 & 0.01008 & 7.34 & $0.0082^{* *}$ \\
\hline D5 & 1 & 0.00265 & 0.00265 & 1.93 & $0.1683^{\mathrm{ns}}$ \\
\hline D6 & 0 & 0 & 0 & 0 & 0 \\
\hline X1.D1 & 1 & 0.00443 & 0.00443 & 3.23 & $0.0760^{\mathrm{ns}}$ \\
\hline X1.D2 & 1 & 0.00008 & 0.00008 & 0.06 & $0.8096^{\mathrm{ns}}$ \\
\hline X1.D3 & 1 & 0.00013 & 0.00013 & 0.10 & $0.7566^{\mathrm{ns}}$ \\
\hline X1.D4 & 1 & 0.00093 & 0.00093 & 0.68 & $0.4121^{\mathrm{ns}}$ \\
\hline X1.D5 & 1 & 0.00167 & 0.00167 & 1.22 & $0.2725^{\mathrm{ns}}$ \\
\hline X1.D6 & 0 & 0 & 0 & 0 & 0 \\
\hline Erro & 82 & 0.11272 & 0.00137 & - & - \\
\hline Total & 93 & 0.28941 & - & - & - \\
\hline
\end{tabular}

Wherein: $\mathrm{FV}=$ source of variation; $\mathrm{GL}=$ degrees of freedom; $\mathrm{SQ}=$ sum of squares; $\mathrm{QM}=$ mean square; $\mathrm{F}=$ calculated $\mathrm{F}$ value; Prob. $>\mathrm{F}=$ level of error probability; $\mathrm{P}=$ relative position in the base-top direction, \%; D"i" = treatments per class $($ Dummy); D"i' $\mathrm{X}=$ treatment interaction (Dummy) with $\mathrm{P}$ variable; ${ }^{* *}=$ significant at the $1 \%$ level of probability; $\mathrm{ns}=$ not significant at the $5 \%$ level of probability. 


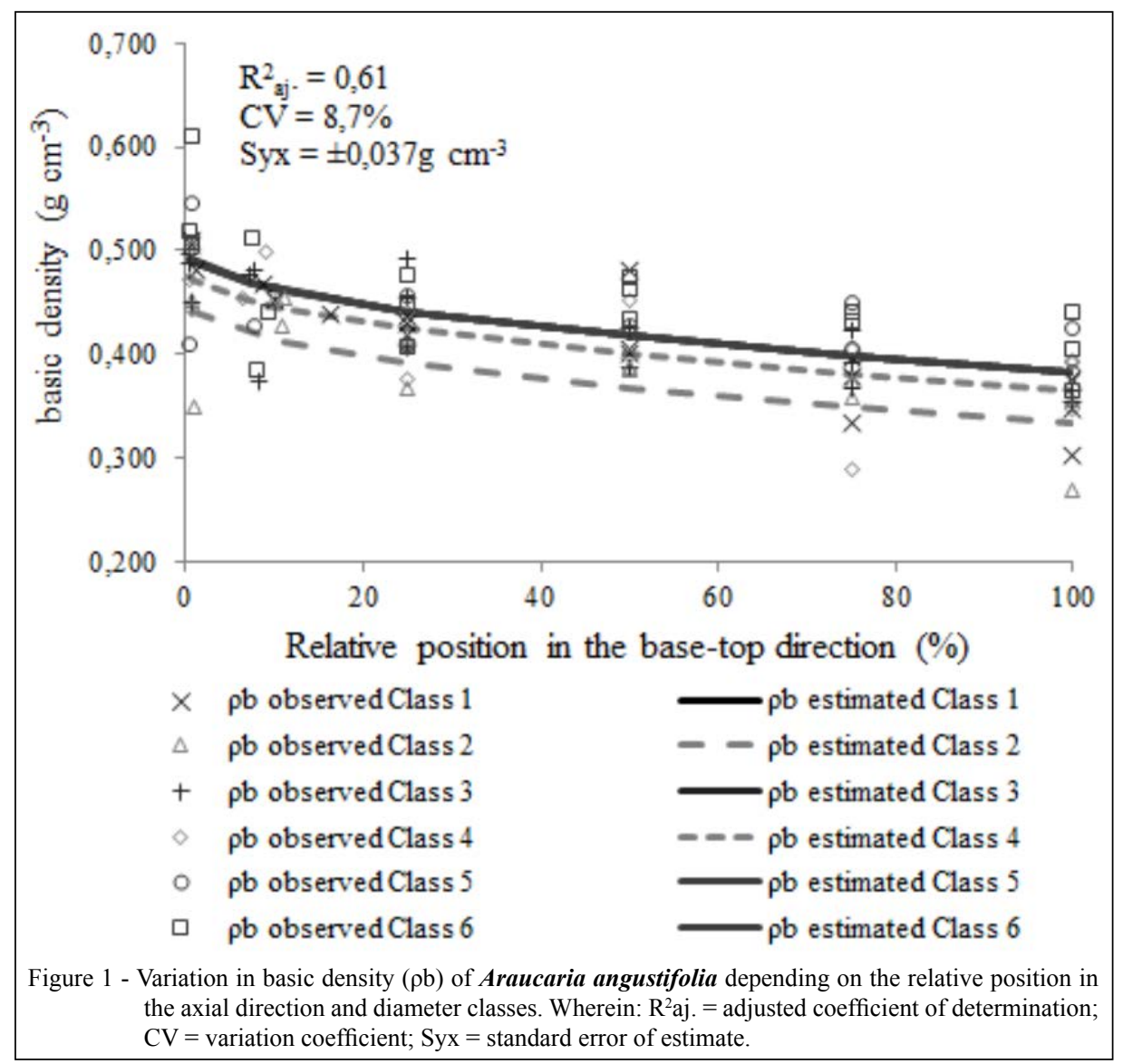

\section{REFERENCES}

EISFELD, R. et al. Chip density modelling using dendrometric variables and disk density. Floresta, Curitiba, v.39, n.4, p.877886, 2009. Available from: <http://ojs.c3sl.ufpr.br/ojs/index. php/floresta/article/view/16324>. Accessed: Jul. 23, 2014. doi: $10.5380 \% 2$ Frf.v39i4.16324.

HILLIG, E. et al. Physical properties of wood from Araucaria angustifolia (Bert.) O. Kuntze as a function of position in the stem at different ages. Cerne, Lavras, v.18, n.2, p.257-263, 2012. Available from: <http://www.scielo.br/pdf/cerne/v18n2/a10v18n2.pdf>. Accessed: Jul. 26, 2014. doi: 10.1590/S0104-77602012000200010.

MATTOS, P.P. et al. Caracterização física, química e anatômica da madeira de Araucaria angustifolia (Bert.) O. Kuntze. Colombo: Embrapa, 2006. 4p. (Comunicado técnico, 160). Available from: <http://www.cnpf.embrapa.br/publica/comuntec/ edicoes/com_tec160.pdf>. Accessed: Jul. 19, 2014.
MATTOS, B.D. et al. Axial variation of wood basic density three gymnosperms species. Revista Brasileira de Ciências Agrárias, Recife, v.6, n.1, p.121-126, 2011. Available from: <http://agraria. pro.br/sistema/index.php?journal $=$ agraria\&page $=$ article $\&$ op $=$ vie w\&path[]=agraria_v6ila1080\&path[] $=888>$. Accessed: Jul. 24, 2014. doi: 10.5039/agraria.v6ila1080.

SAS (STATISTICAL ANALYSIS SYSTEM): Programa de computador, ambiente VM. Cary, 1993. Versão 6.08.

VITAL, B.R. Métodos de determinação da densidade da madeira. Viçosa: SIF/ UFV, 1984. 21p. (Boletim Técnico, 1).

WASHUSEN, R. et al. Effect of thinning and fertilizer on the cellulose crystallite width of Eucalyptus globulus. Wood Science and Technology, Berlin, v.39, n.7, p.569578, 2005. Available from: <http://www.springerlink.com/ content/nk20123vj821731t/>. Accessed: Jul. 20, 2014. doi: 10.1007/s00226-005-0012-2. 